\section{Effect of Acidic Solutions on the Surface Degradation of a Micro-Hybrid Composite Resin}

\author{
Eliseu A. Münchow, ${ }^{1}$ Ana Cláudia A. Ferreira, ${ }^{1}$ Raissa M. M. Machado, ${ }^{1}$ Tatiana \\ S. Ramos, ${ }^{2}$ Sinval A. Rodrigues-Junior, ${ }^{3}$ Cesar H. Zanchi ${ }^{1}$
}

\author{
'Department of Operative \\ Dentistry, School of Dentistry, \\ UFPEL - Federal University of \\ Pelotas, Pelotas, RS, Brazil \\ ${ }^{2}$ Biomaterials Development \\ and Control Center (CDC-Bio), \\ UFPEL - Federal University of \\ Pelotas, Pelotas, RS, Brazil \\ ${ }^{3}$ Health Sciences Postgraduate \\ Program, Community University \\ of the Region of Chapecó - \\ Unochapecó, Chapecó, SC, Brazil
}

Correspondence: Prof. Dr. Eliseu A. Münchow, Rua Gonçalves Chaves, 457, 96015-560 Pelotas, RS, Brasil. Tel: +55-53-3222-6690, e-mail: eliseumunchow@hotmail.com

\section{Introduction}

Dental composite resins had their properties and characteristics substantially improved since they were introduced in dentistry (1), leading to an excellent acceptance by the dentists who can use them for a variety of clinical procedures. They are basically constituted by an organic matrix and inorganic fillers chemically connected by a silane substance. Regarding the organic matrix, which is mostly formulated with dimethacrylate monomers such as 2,2-bis[4-(2-hydroxy-3-methacryloyloxypropyl)phenyl]propane (Bis-GMA), triethyleneglycol dimethacrylate (TEGDMA), and urethane dimethacrylate (UDMA), it constitutes the body of the composite and may influence the handling ability and properties of the material; on the other hand, silica and glass fillers are commonly used to modify esthetic, physical and mechanical characteristics of composites (1).

In contact with the oral environment, composite resins undergo wear and are affected by chemical substances in their surroundings, acting superficially on the material's structure. Even though a great variety of substances may be present at the oral environment, water, saliva, acids, bases, salts, and alcohols have been related to the reduction of hardness, flexural strength and flexural modulus properties $(2,3)$. In addition, the biofilm accumulated over the restoration can produce acidic substances that may imply surface degradation, leading to the material's softening and surface roughening $(4,5)$. With regard to these acidic substances, the lactic, propionic and acetic acids are commonly found in the oral environment and they are used as storage solutions for screening accelerated hydrolysis phenomena of composite resins (6) and increase of hygroscopic expansion of Bis-GMA-based materials.

Even though chemical substances may affect more actively the organic matrix of composites, the type, size, and concentration of fillers may also influence the material's resistance to degradation. Considering this, micro-hybrid composites present a mixture of silica and glass fillers which vary between 0.4 to $1 \mu \mathrm{m}$ in size and present a concentration of approximately $66 \mathrm{wt} \%$. They are indicated for the restoration of both anterior and posterior teeth, resulting in excellent mechanical and esthetic properties, in addition to good polishability (1). Though, since dimethacrylate-based composites undergo degradation in contact with different substances found in the oral cavity, it is important to evaluate the influence of these substances on the surface properties of micro-hybrid composites, and also to evaluate whether their $\mathrm{pH}$ affects the degradation potential imposed to the material.

The aim of this in vitro study was to evaluate the 
effect of acidic solutions on the superficial properties of a micro-hybrid composite resin testing the variation of surface roughness, hardness, and sorption and solubility. The first hypothesis tested was that the $\mathrm{pH}$ is determinant of the composite's surface aggressiveness; and the second hypothesis tested was that the most acidic solutions affect more negatively the evaluated properties.

\section{Material and Methods}

\section{Specimen Preparation and Group Allocation}

The micro-hybrid composite resin Filtek Z-250 ${ }^{\mathrm{Tm}}$ (3M ESPE, St. Paul, MN, USA) was investigated in this study. Eighty disc-shaped specimens $(6 \mathrm{~mm}$ in diameter $\times 1 \mathrm{~mm}$ thick) were prepared using a Teflon mold. The composite was placed in a single increment and covered with a glassslide that was pressured to extrude excess material. Then, each specimen was photo-activated with a light-emitting

Table 1. Storage solutions used in this study and their molecular formula and molecular structure

Storage solution
$\begin{gathered}\text { Molecular } \\ \text { formula }\end{gathered}$

diode curing unit (LED Radii; Bayswater, VIC, Australia) for $20 \mathrm{~s}$ on the top and bottom surfaces and polished with \#600- and \#1200-grit silicon carbide abrasive papers.

After their preparation, all specimens were randomly allocated into eight groups according to the storage solution ( $n=10)$ : deionized water (Water); $75 / 25$ vol\% ethanol/water solution (Ethanol); $85 \mathrm{vol} \%$ lactic acid (LA PA); $0.02 \mathrm{~N}$ lactic acid (LA $0.02 \mathrm{~N}$ ); 99 vol\% propionic acid (PA PA); $0.02 \mathrm{~N}$ propionic acid (PA 0.02N); 99 vol\% acetic acid (AA PA); or $0.02 \mathrm{~N}$ acetic acid (AA $0.02 \mathrm{~N}$ ). The molecular formula and molecular structure of each solution is shown in Table 1.

\section{Baseline Surface Analysis}

Before storage in the solutions, hardness and surface roughness measurements were obtained for each specimen. Hardness was evaluated using a microhardness tester (FM 700; Future Tech, Chung Ho, Taipei Hsien, Taiwan), with a $50 \mathrm{~g}$ load and a dwell time of $15 \mathrm{~s}$. Three indentations were made across the center of each specimen, and the Knoop Microhardness Number (KMN) was obtained. The baseline mean hardness value was classified as $\mathrm{KMN}_{0}$. Surface roughness was measured by a single evaluator who rotated the specimens over the surface profilometer (Surfcorder SE1200; Kosaka Lab., Tokyo, Japan) clockwise at 3, 6 and 9 $h$ angles. The mean roughness parameter $(R a, \mu m)$ for each specimen was recorded as the average of three readings. This baseline roughness measurement was classified as $\mathrm{Ra}_{0}$.

\section{pH Measurement}

The $\mathrm{pH}$ of all the solutions was verified by a digital pHmeter (PM 608 Plus; Analion, Ribeirão Preto, SP, Brazil) adding $20 \mu \mathrm{L}$ of each solution in glass vessels, except of the PA solutions, which could not be measured as they had no water to ionize the acidic molecules. All the $\mathrm{pH}$ measurements were performed three times at $23{ }^{\circ} \mathrm{C}$ and $50 \%$ relative humidity.

\section{Sorption and Solubility Analysis}

After baseline measurements, all specimens were prepared for a sorption and solubility test, which was performed following the ISO 4049:2009 standard (7) and placed in a desiccator at $37{ }^{\circ} \mathrm{C}$ containing freshly dried silica gel and calcium chloride. After $24 \mathrm{~h}$, the samples were removed, stored in a desiccator at $23^{\circ} \mathrm{C}$ for $1 \mathrm{~h}$ and weighed on a scale with a $0.01 \mathrm{mg}$ precision (AUW 220D; Shimadzu Corp. Nakagyo-ku, Kyoto, Japan). This cycle was repeated until a constant mass $\left(m_{1}\right)$ was obtained. Thickness and diameter of the specimens were measured at five points using a digital caliper ( $0.01 \mathrm{~mm}$ precision), rounded off to the nearest, and these measurements were used to calculate the volume (V) of each specimen (in $\mathrm{mm}^{3}$ ). 
Next, the specimens were immersed in the solutions at $37^{\circ} \mathrm{C}$ for 7 days, then removed, blotted dry and weighed $\left(m_{2}\right)$. After weighing, they were dried again inside the desiccators and weighed daily to record a third constant mass $\left(m_{3}\right)$ (as previously described). For each sample, the data of sorption (SO) and solubility (SL) were calculated using the following formula:

$$
\text { SO }=\left(m_{2}-m_{3}\right) / V \text { and SL }=\left(m_{1}-m_{3}\right) / V
$$

\section{Hardness and Surface Roughness Variation}

After the SO and SL evaluation, each group was measured again for the hardness and surface roughness tests, as aforementioned; so, the final mean hardness $\left(\mathrm{KMN}_{1}\right)$ and mean roughness $\left(\mathrm{Ra}_{1}\right)$ were obtained, and the variation between the baseline and the final measurements were calculated as follows:

$$
\Delta \mathrm{KMN}=\mathrm{KMN}_{0}-\mathrm{KMN}_{1} ; \text { and } \Delta \mathrm{Ra}=\mathrm{Ra}_{1}-\mathrm{Ra}_{0} .
$$

\section{Statistical Analysis}

The hardness and surface roughness data (baseline and final measurements) were analyzed by paired t-tests. Data from hardness and surface roughness variation ( $\triangle K M N$ and $\triangle \mathrm{Ra}$, respectively) and the sorption and solubility data were all analyzed by one-way ANOVA and Tukey as a post hoc test. A significance level of $5 \%$ was set for all analyses.

\section{Results}

\section{Hardness and Surface Roughness}

The baseline and final hardness and surface roughness mean values are graphically demonstrated in Figures 1 and 2 , respectively. With the hardness results, the storage solutions degraded the material, since the specimens became significantly softer, except for those immersed in deionized water and in lactic acid $0.02 \mathrm{~N}$ $(p=0.084$ and $p=0.687$, respectively) (Fig. 1). Regarding the $\triangle K M N$ results, propionic acid PA caused the highest variation, but statistically similar to the other solutions, except for the $0.02 \mathrm{~N}$ lactic acid, which showed the lowest $\triangle K M N$ mean value $(p<0.001)$ (Table 2$)$. With regard to the surface roughness evaluation, all storage solutions produced rougher surfaces on the specimens $(p<0.001)$ (Fig. 2). However, the $\triangle$ Ra results did not vary among the groups, ranging from 0.04 to $0.06 \mu \mathrm{m}$ (AA PA and PA 0.02 $\mathrm{N}$ groups, respectively) (Table 2).

\section{Sorption and Solubility}

The sorption and solubility results are demonstrated in Table 2. All the solutions provided similar sorption effect to the specimens $(p=0.484)$; in contrast, while the $0.02 \mathrm{~N}$

Table 2. Surface roughness $(\Delta \mathrm{Ra}-\mu \mathrm{m})$ and microhardness $(\Delta \mathrm{KMN})$ variation, sorption $(\mathrm{S} 0)$ and solubility (SL) data in $\mu \mathrm{g} / \mathrm{mm} 3$, standard deviation (SD) and $\mathrm{pH}$ of the solutions evaluated.

\begin{tabular}{lccccc}
\hline Group & $\Delta \mathrm{KMN}$ & $\Delta \mathrm{Ra}$ & $\mathrm{SO}$ & $\mathrm{SL}$ & $\mathrm{pH}$ \\
\hline Water & $10.5^{\mathrm{AB}}$ & $0.05^{\mathrm{A}}$ & $22.5(4.7)^{\mathrm{A}}$ & $0.7(8.9)^{\mathrm{AB}}$ & $4.6(0.6)$ \\
Ethanol & $14.4^{\mathrm{AB}}$ & $0.05^{\mathrm{A}}$ & $25.6(7.8)^{\mathrm{A}}$ & $-3.4(5.6)^{\mathrm{AB}}$ & $6.6(0.1)$ \\
LA PA & $15.3^{\mathrm{AB}}$ & $0.05^{\mathrm{A}}$ & $26.7(13.9)^{\mathrm{A}}$ & $-0.3(10.1)^{\mathrm{AB}}$ & - \\
LA 0.02N & $-1.9^{\mathrm{B}}$ & $0.06^{\mathrm{A}}$ & $20.5(6.1)^{\mathrm{A}}$ & $-13.3(12.3)^{\mathrm{B}}$ & $2.5(0.1)$ \\
PA PA & $20.7^{\mathrm{A}}$ & $0.04^{\mathrm{A}}$ & $19.0(10.1)^{\mathrm{A}}$ & $4.1(13.0)^{\mathrm{A}}$ & - \\
PA 0.02N & $15.9^{\mathrm{AB}}$ & $0.05^{\mathrm{A}}$ & $23.5(7.5)^{\mathrm{A}}$ & $-1.0(9.5)^{\mathrm{AB}}$ & $3.0(0.1)$ \\
AA PA & $16.5^{\mathrm{AB}}$ & $0.05^{\mathrm{A}}$ & $23.2(6.0)^{\mathrm{A}}$ & $-6.5(9.1)^{\mathrm{AB}}$ & - \\
AA 0.02N & $12.9^{\mathrm{AB}}$ & $0.05^{\mathrm{A}}$ & $26.6(11.9)^{\mathrm{A}}$ & $1.7(10.1)^{\mathrm{A}}$ & $3.01(0.1)$ \\
\hline
\end{tabular}

Different superscripts capital letters in a same column represent statistically significant differences among the storage solutions $(p<0.001)$.

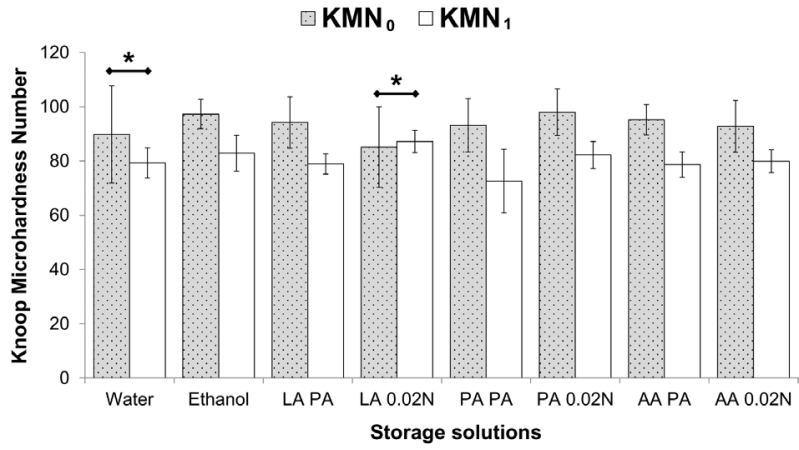

Figure 1. Mean hardness values of the composite resin before $\left(\mathrm{KMN}_{0}\right)$ and after $\left(\mathrm{KMN}_{1}\right)$ storage in deionized water (Water), 75/25 vol\% ethanol/ water solution (Ethanol), 85 vol\% lactic acid (LA PA), $0.02 \mathrm{~N}$ lactic acid (LA $0.02 \mathrm{~N}), 99 \mathrm{vol} \%$ propionic acid (PA PA), $0.02 \mathrm{~N}$ propionic acid (PA $0.02 \mathrm{~N}$ ), $99 \mathrm{vol} \%$ acetic acid (AA PA), and $0.02 \mathrm{~N}$ acetic acid (AA $0.02 \mathrm{~N}$ ). The horizontal line with asterisk $\left(^{*}\right)$ indicates similarity between the baseline and the final measurements ( $p>0.05)$.

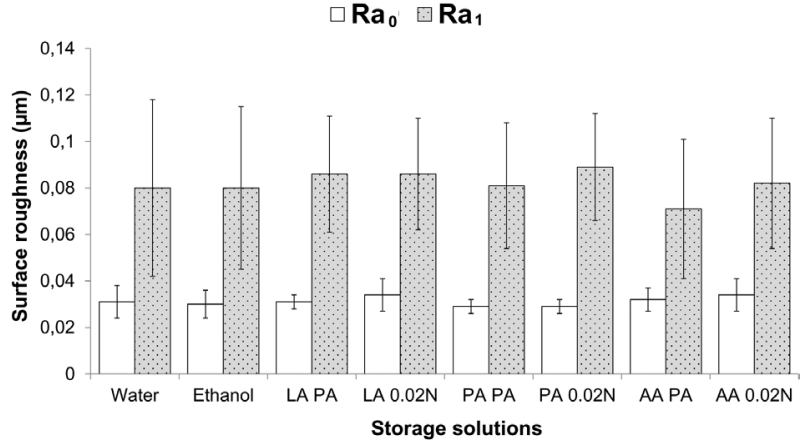

Figure 2. Mean surface roughness values of the composite resin before $\left(\mathrm{Ra}_{0}\right)$ and after $\left(\mathrm{Ra}_{1}\right)$ storage in deionized water (Water), 75/25 vol\% ethanol/water solution (Ethanol), 85 vol\% lactic acid (LA PA), $0.02 \mathrm{~N}$ lactic acid (LA 0.02N), 99 vol\% propionic acid (PA PA), $0.02 \mathrm{~N}$ propionic acid (PA 0.02N), 99 vol\% acetic acid (AA PA), and $0.02 \mathrm{~N}$ acetic acid (AA $0.02 N$ ). All solutions increased significantly the surface roughness of the composite resin $(\mathrm{p}<0.001)$. 
lactic acid caused the lowest solubility result in the study, the propionic acid PA and the $0.02 \mathrm{~N}$ acetic acid showed the highest mean solubility values.

\section{pH Measurement}

Table 2 shows the $\mathrm{pH}$ values of the evaluated solutions. The ethanol solution presented the highest $\mathrm{pH}$ in the study (6.6); deionized water showed a $\mathrm{pH}$ of 4.6. The $0.02 \mathrm{~N}$ acidic solutions diluted in water presented the lowest $\mathrm{pH}$ values, and the lactic acid was the most acidic solution $(\mathrm{pH}=2.5)$.

\section{Discussion}

Several studies have demonstrated that acidic substances have a potential of degrading composite resin materials $(5,8-10)$. Thus, one expects that any solution with low $\mathrm{pH}$ would increase the surface degradation processes, being more aggressive than the less acidic solutions. Nevertheless, the first study hypothesis that the $\mathrm{pH}$ of the storage solutions would determine the aggressiveness of the solutions on the composite's surface was totally rejected, as even the lowest and the highest $\mathrm{pH}$ values altered the composite's superficial properties in a similar fashion, suggesting that other factors are influencing more the surface and structure degradation of resin-based materials.

According to Bagheri et al. (11), the type of storage solution and the composition of the soaked material are important factors for the degradation of composite materials. On the other hand, factors such as the solubility parameter [from both the storage solution (solvent) and the polymeric material (solute)], the cross-link nature of the resin matrix, and the solvent sorption uptake may influence more directly the polymer's degradation rate (12). Consequently, the combination of these factors may affect the wear undergone by the restorative material and its durability.

Independent from the factors involved in superficial degradation processes, data analysis revealed that the acidic solutions altered the hardness and surface roughness of the investigated composites (Figs. 1 and 2). These solutions were chosen because they can be used as ageing simulators, with water simulating the wet oral environment (9), the ethanol-water solution representing the medium of choice for accelerated ageing $(9,13)$, and the organic acids simulating the substances that may be produced by dental biofilm $(4,13-15)$, which would be in intimate contact with the restorative material's surface. Hardness is defined as the resistance of a material to permanent deformation, tested by means of an indentation, and is related to the microstructure and composition of the composite resin $(16,17)$. Therefore, any factor affecting the resin matrix arrangement, the matrix/filler interaction or the filler particles, leading to leaching of these components, causes a significant reduction on its surface properties, including hardness.

The results showed that all the solutions, except deionized water and $0.02 \mathrm{~N}$ lactic acid, reduced the hardness of specimens (Fig. 1). According to Lee et al. (4), 75\% ethanol solution presents a close solubility parameter [(3.12 $\left.\times 10^{-4} \mathrm{~J} / \mathrm{m}^{3}\right)^{1 / 2}$ ] (18) to Bis-GMA-based materials (e.g.: Filtek $\left.\mathrm{Z}-250^{\mathrm{TM}}\right)$, and the closer the solubility parameter between solvent and solute, the greater the solute's degradation (14). In fact, and according to Wu and McKinney (19) the surface of any Bis-GMA-based material would be softened by solvents with solubility parameter ranging from 1.82 to $2.97 \times 10^{-4}\left(\mathrm{~J} / \mathrm{m}^{3}\right)^{1 / 2}$. Regarding the organic acids used in the present study, the propionic and the acetic acids have solubility parameter similar to ethanol (4) and, as a consequence, they resulted in reduction of hardness. On the other hand, deionized water and $0.02 \mathrm{~N}$ lactic acid maintained stable the hardness of specimens, probably because both of them have a solubility parameter which is not similar to Bis-GMA-based materials. These results corroborate a previous study that found that propionic and acetic acids softened the evaluated composites, while water and lactic acid solutions did not affect hardness (4).

Unlike hardness, all the solutions increased surface roughness of specimens (Fig. 2). Surface roughness measures the material's topography and depends on several factors, namely the type of fillers, their size, shape and concentration (20), the resin matrix conversion percentage (21), the fillermatrix interaction $(9,21)$, and the hardness of the material (22). In this study, these factors were kept the same; thus, the differences obtained are specifically due to the effect of the solutions on the material's surface and structure. Several studies have demonstrated that acidic solutions increase the roughness of composites, probably because they soften their surface, leading to the leachability of resin components and, in consequence, to the displacement of filler particles, contributing to the formation of a rough surface $(8,23,24)$. In fact, all the solutions that softened the composite resin also increased its surface roughness (Fig. 2), although there were no significant differences among the roughness variation data (Table 2). However, even though deionized water and $0.02 \mathrm{~N}$ lactic acid did not alter the specimen's hardness significantly (softening effect), the specimen's surface roughness was increased, a fact that may be explained by the sorption and solubility phenomena (14).

Sorption and solubility are related to the solvent entrance into the resin matrix, which may alter its structure by swelling and plasticization processes, and finally to the release of non-reacted components and byproducts of the polymer network (14). In the present study, deionized water and ethanol solution were used as positive and 
negative controls, respectively. Even though water was less deleterious to composite as it did not significantly reduce hardness, Filtek Z-250 was sensible to water uptake, probably due to the presence of TEGDMA in its composition, which is hydrophilic and may imply in high sorption. Nevertheless, all solutions showed similar sorption results (Table 2), probably because this characteristic is more material-dependent, that is, more influenced by the hydrophilicity and the cross-linking nature of the resin matrix, than by the type of solvent (25). Considering that the same composite resin was evaluated, all solvents were able to cause similar sorption effect. It is also important to observe that all sorption values of this study were lower than the reference values of ISO 4049 (7).

With regard to solubility, it is possible to observe that all the storage solutions caused a low solubility effect (Table 2) also lower than the reference value of ISO 4049, demonstrating that the composite resin was structurally stable after the immersion procedures. Interestingly, the LA $0.02 \mathrm{~N}$ group showed a high negative solubility value (additional to the highest standard deviation value obtained) when compared with the other groups. This indicates that some lactic acid molecules, which are constituted by a pendant hydroxyl polar group (Table 1), have probably interacted by hydrogen bonds with the composite structure, resulting in reduced release of byproducts (products of solvent degradation or released by the polymer's structure) (13). This may also explain why the $0.02 \mathrm{~N}$ lactic acid did not reduce the microhardness of the composite resin (Fig. 1), showing the lowest $\triangle K M N$ (Table 2).

Another purpose of the present study was to investigate whether the most acidic solutions would affect more negatively the evaluated properties (second tested hypothesis). Comparing the findings of the study with each other it is possible to detect that the $0.02 \mathrm{~N}$ lactic acid showed the lowest $\mathrm{pH}$ value and equally the lowest aggressiveness to the material's structure: same hardness before and after the immersion procedure, same sorption and lower solubility effects when compared with the other solutions, and similar surface roughness variation (Figs. 1 and 2, and Table 2). Thus, the second tested hypothesis was also rejected. According to a recent study (6), which investigated the effects of neutral and extremely acidic or alkaline $\mathrm{pH}$ storage media on dental resin surface properties, the alkaline $\mathrm{pH}$ was more aggressive to hardness and surface roughness properties, while the evaluated composites seemed to withstand the neutral and acidic media environments.

The evaluated micro-hybrid composite resin had its surface properties influenced by the storage solutions where they were immersed. In addition, the $0.02 \mathrm{~N}$ lactic acid presented the most acidic nature, but reduced surface aggressiveness. Therefore, a low $\mathrm{pH}$ value does not seem to be a significant factor affecting the surface degradation of the evaluated composite resin. However, further investigations evaluating the effect of these solutions on mechanical and surface properties of composite resin materials containing different types, sizes and content of fillers are required.

\section{Resumo}

Resinas compostas podem sofrer desgaste pela ação de substâncias químicas (saliva, álcool, ácidos bacterianos) presentes no ambiente oral, que podem afetar a estrutura e as propriedades superficiais do material. Assim, este estudo avaliou o efeito de substâncias ácidas nas propriedades superficiais de uma resina composta micro-hibrida (Filtek Z-250). Oitenta espécimes foram preparados e mensurados quanto à dureza e rugosidade superficial iniciais $\left(\mathrm{KMN}_{0}\right.$ e $\mathrm{Ra}_{0}$, respectivamente). Os espécimes foram submetidos a testes de sorção (SO) e solubilidade (SL) de acordo com a ISO 4049:2009, porém usando diferentes soluções de armazenamento: água deionizada, solução etanol/água 75/25\% em volume, ácido lático, ácido propiônico e ácido acético. Os ácidos foram utilizados em duas concentrações: PA e 0,02 N. 0 pH foi mensurado para todas as soluções e a dureza e rugosidade superficial finais $\left(\mathrm{KMN}_{1} \mathrm{e} \mathrm{Ra}_{1}\right.$, respectivamente) foram mensuradas. Os dados foram analisados com testes t-pareado e ANOVA a um fator, e teste de Tukey $(p<0,05)$. Todas as soluções reduziram a dureza e aumentaram os valores de Ra, exceto para os espécimes armazenados em água e ácido lático 0,02 N, que mantiveram a dureza. Todas as soluções produziram fenômenos de S0 e SL similares, exceto o ácido lático 0,02 $\mathrm{N}$, que causou menor solubilidade do que as outras soluções. Etanol mostrou o maior $\mathrm{pH}(6,6)$ e o ácido lático $0,02 \mathrm{~N}$ o menor deles $(2,5)$. As soluções afetaram negativamente as propriedades superficiais da resina composta; além disso, um pH ácido não parece ser um fator significante para intensificar os fenômenos de degradação superficial.

\section{References}

1. Ferracane JL. Resin composite--state of the art. Dent Mater 2011;27:29-38.

2. Almeida GS, Poskus LT, Guimarães JG, da Silva EM. The effect of mouthrinses on salivary sorption, solubility and surface degradation of a nanofilled and a hybrid resin composite. Oper Dent 2010;35:105-111.

3. Sideridou ID, Karabela MM. Sorption of water, ethanol or ethanol/water solutions by light-cured dental dimethacrylate resins. Dent Mater 2011;27:1003-1010.

4. Lee SY, Huang HM, Lin CY, Shih YH. Leached components from dental composites in oral simulating fluids and the resultant composite strengths. J Oral Rehabilit 1998;25:575-588.

5. Silva KG, Pedrini D, Delbem AC, Cannon M. Effect of $\mathrm{pH}$ variations in a cycling model on the properties of restorative materials. Oper Dent 2007;32:328-335.

6. Cilli R, Pereira JC, Prakki A. Properties of dental resins submitted to $\mathrm{pH}$ catalysed hydrolysis. J Dent 2012;40:1144-1150.

7. Dentistry-Polymer based filling, restorative and luting materials. 4th ed. Geneva: ISO 4049: 2009.

8. Briso AL, Caruzo LP, Guedes AP, Catelan A, dos Santos PH. In vitro evaluation of surface roughness and microhardness of restorative materials submitted to erosive challenges. Oper Dent 2011;36:397-402.

9. Kooi T, Tan Q, Yap A, Guo W, Tay K, Soh M. Effects of food-simulating liquids on surface properties of giomer restoratives. Oper Dent 2012;37:665-671.

10. Turssi $C P$, Hara $A T$, de Magalhães $C S$, Serra $M C$, Rodrigues $A L$, Jr. Influence of storage regime prior to abrasion on surface topography of restorative materials. J Biomed Mater Res B Appl Biomater 2003;65:227-232.

11. Bagheri R, Tyas MJ, Burrow MF. Subsurface degradation of resin-based composites. Dent Mater 2007;23:944-951. 
12. Gopferich A. Mechanisms of polymer degradation and erosion. Biomaterials 1996;17:103-114.

13. Yap AU, Tan SH, Wee SS, Lee CW, Lim EL, Zeng KY. Chemical degradation of composite restoratives. J Oral Rehabil 2001;28:1015-1021.

14. Ferracane JL. Hygroscopic and hydrolytic effects in dental polymer networks. Dent Mater 2006;22:211-222.

15. Willershausen B, Callaway $A$, Ernst CP, Stender E. The influence of oral bacteria on the surfaces of resin-based dental restorative materials--an in vitro study. Int Dent J 1999;49:231-239.

16. dos Reis AC, de Castro DT, Schiavon MA, da Silva U, Agnelli JA. Microstructure and mechanical properties of composite resins subjected to accelerated artificial aging. Braz Dent J 2013;24:599-604.

17. Rodrigues SA, Jr., Ferracane JL, Della Bona A. Flexural strength and Weibull analysis of a microhybrid and a nanofill composite evaluated by 3- and 4-point bending tests. Dent Mater 2008;24:426-431.

18. McKinney JE, Wu W. Chemical softening and wear of dental composites. J Dent Res 1985;64:1326-1331.

19. Wu W, McKinney JE. Influence of chemicals on wear of dental composites. J Dent Res 1982;61:1180-1183.

20. Beun S, Glorieux T, Devaux J, Vreven J, Leloup G. Characterization of nanofilled compared to universal and microfilled composites. Dent
Mater 2007;23:51-59.

21. Marghalani HY. Effect of filler particles on surface roughness of experimental composite series. J Appl Oral Sci 2010;18:59-67.

22. Munchow EA, Correa MB, Ogliari FA, Piva E, Zanchi CH. Correlation between surface roughness and microhardness of experimental composites with varying filler concentration. J Contemp Dent Pract 2012;13:299-304.

23. Abu-Bakr N, Han L, Okamoto A, Iwaku M. Changes in the mechanical properties and surface texture of compomer immersed in various media. J Prosthet Dent 2000;84:444-452.

24. Badra W, Faraoni JJ, Ramos RP, Palma-Dibb RG. Influence of different beverages on the microhardness and surface roughness of resin composites. Oper Dent 2005;30:213-219.

25. Ogliari FA, Ely C, Zanchi CH, Fortes CB, Samuel SM, Demarco FF, et al. Influence of chain extender length of aromatic dimethacrylates on polymer network development. Dent Mater 2008;24:165-171.

Received April 16, 2014 Accepted July 28, 2014 